\title{
The effect of a lesion of the habenula on passive avoidance learning'
}

KENT B. DAVIS, MICHAEL STEVENSON22, ANSTISS H, MCIVER AND HAROLD C. NIELSON VA HOSPITAL, SEPULVEDA, CALIFORNIA AND UNIVERSITY OF CALIFORNIA, LOS ANGELES

To investigate whether habenular lesions affect passive avoidance learning and thyroid functioning, and to determine whether cold stress modifies lesion effects, rats with habenular lesions and sham operate control were cold stressed or not cold stressed, and then given passive avoidance training. Habenular rats learned to avoid faster than controls. Cold stress did not affect learning or modify the lesion effects. Following training, blood samples were analyzed for protein-bound and inorganic iodine. Both cold stress and habenular lesions decreased inorganic iodine level.

The role of the habenula in influencing or regulating behavior is poorly understood. Despite the fact that the habenula is considered part of the limbic system, which is thought to mediate emotional behavior, lesions of the habenula apparently do not lead to marked changes in emotional behavior. Brady \& Nauta (1955) found that habenular lesions did not increase emotional reactivity in rats as measured by either a behavioral rating scale or the magnitude of a startle response, or alter the acquisition and retention of a conditioned emotional response. Similarly, Nielson \& McIver (1966) found no changes in the emotionality of habenular rats as measured by open field defecation. If anything, habenular lesions may reduce emotional reactivity. Brady \& Nauta (1955) found that conditioned emotional responses extinguished more rapidly in habenular rats, and Nielson \& McIver (1966) found habenular lesions increased open field ambulation.

Recently another function of the habenula has been suggested. Mess (1964) has implicated this structure in the thyroidal response to cold. He reported elevated thyroid iodine/serum iodine $(\mathrm{T} / \mathrm{S})$ ratios in rats with habenular lesions following moderate cold stress. Furthermore, Nielson \& McIver (1966) found that some of the behavioral effects of a cold stress were opposite to those produced by habenular lesions. Compared to controls, rats with habenular lesions explored more and learned an active avoidance response more slowly while intact cold stressed rats explored less and learned an active avoidance response faster. Also, they found that cold stress may modify the effects of habenular lesions on these behaviors since cold-stressed habenular rats explored less and learned better than lesioned animals not cold-stressed.

The following experiment was conducted to determine the effects of habenular lesions upon the acquisition of a passive avoidance response, and to determine whether cold stress modifies the effects of habenular lesions on passive avoidance learning. In addition, determi- nations of serum iodine, as an indicant of thyroid functioning, were made.

Subjects

The Ss were 60 adult male Wistar rats that were randomly divided into two groups. In one group lesions were placed in the habenula. The other group was subjected to the same surgical procedure except that the electrode was not inserted into the brain.

\section{Apparafus}

Passive avoidance training was given in a plexiglas box, 31 in. square, with translucent walls 14 in. high and a grid floor. A $4-1 / 2 \times 4-1 / 2$ in. platform was located in the center of the floor which could be lowered from $5 \mathrm{in}$. to $2 \mathrm{in}$. above the floor. When the platform was lowered to $2 \mathrm{in}$. above the grid floor a microswitch was closed which activated a stopwatch. When S stepped off the platform the stopwatch was immediately deactivated and a constant current of $1 \mathrm{ma}$. was delivered to the grid floor.

\section{Method and Procedure}

Two to four weeks after surgery, Ss were placed on a 12-hr. food deprivation schedule for the remainder of the experiment. Five days after initiation of the feeding schedule, half of the habenular Ss and half of the controls were given a daily $90-\mathrm{sec}$. ice-water bath that dropped the rectal temperatures approximately $5^{\circ} \mathrm{C}$, for five consecutive days. The remainder of the Ss were merely removed from the home cage and held in E's hand for approximately $15 \mathrm{sec}$. Twenty-four hr. after the last cold stress, avoidance training was initiated. The Swas placed on the raised platform which was then lowered. Upon stepping off the platform, $S$ received a 1 ma grid shock for $4 \mathrm{sec}$. The Ss were given one trial a day until they reached the criterion of remaining on the platform for $60 \mathrm{sec}$. or until they had received a daily trial for 10 days. Eleven days after training had started, all Ss were given a 90-sec. ice-water bath. On the twelfth day they were guillotined and blood samples taken for analysis of protein-bound and inorganic iodine levels at BioTechnics Laboratories, Inc., Los Angeles by a method described by Barker, Humphrey \& Soley (1951). Brains were taken, sectioned, stained, and referred to the atlas of De Groot (1959) for verification of site and extent of the lesions.

\section{Resulfs}

Histological analyst's showed that $17 \mathrm{Ss}$ had sustained at least $80 \%$ damage to the habenula. Nine of these had been subjected to cold stress while the other eight had not. The results reported here are based on these animals and are summarized in Table 1. Rats with lesions 
Table 1. Means of the Four Measures as a Function of Cold Stress and Habenular Lesions

\begin{tabular}{|c|c|c|c|c|}
\hline \multirow[b]{2}{*}{ Measures } & \multicolumn{2}{|c|}{ Lesion } & \multicolumn{2}{|c|}{ No Lesion } \\
\hline & $\begin{array}{l}\text { Cold } \\
\text { Stress }\end{array}$ & $\begin{array}{l}\text { No Cold } \\
\text { Stress }\end{array}$ & $\begin{array}{l}\text { Cold } \\
\text { Stress }\end{array}$ & $\begin{array}{l}\text { No Cold } \\
\text { Stress }\end{array}$ \\
\hline \multirow{3}{*}{$\begin{array}{l}\text { First Trial } \\
\text { Latencies (sec.) } \\
\text { Trials to Criterion }\end{array}$} & & & & \\
\hline & 10.70 & 10.80 & 1.90 & 1.20 \\
\hline & 2.90 & 2.40 & 6.20 & 5.20 \\
\hline $\begin{array}{l}\text { Serum Inorganic } \\
\text { lodine }(\mu \mathrm{g} / 100 \mathrm{ml} \text {.) }\end{array}$ & 0.80 & 0.85 & 1.05 & 1.20 \\
\hline $\begin{array}{c}\text { Serum Protein-Bound } \\
\text { lodine }(\mu \mathrm{g} / 100 \mathrm{ml} .)\end{array}$ & 6.95 & 6.35 & 6.25 & 6.30 \\
\hline
\end{tabular}

of the habenula had significantly longer first trial latencies $(p<.001)$ than controls. Cold stress did not alter first trial latencies and it did not interact with lesion effects. Animals with lesions of the habenula also learned to remain on the platform faster than the controls or the cold-stressed animals $(p<.001)$. Again there was no interaction of cold stress and habenular lesion effects.

No differences in protein-bound iodine levels were found for any groups. However, analysis of the inorganic iodine levels showed that cold stress prior to learning $(p<.05)$ and habenular lesions $(p<.001)$ reduced inorganic iodine levels. For each of the four groups, correlations between the protein-bound and inorganic iodine levels and the two behavioral measures, trials to criterion and first trial latencies, were computed. Protein-bound iodine levels did not correlate with behavior for any group. However, inorganic iodine levels were related to first trial latency for the cold-stressed controls (rank order correlation .61, $\mathrm{p}<.02$ ) and for habenular rats not cold-stressed (Kendall's Tau .73, $\mathrm{p}<.007$ ). In both cases the relationships were inverse with longer latencies being associated with lower inorganic iodine levels.

\section{Discussion}

The major finding of this experiment is that habenular rats acquire a passive avoidance response faster than controls. The acquisition of a CER also involves the withholding of a response tendency, i.e. the cessation of an acquired lever pressing response to water reinforcement. In that situation Brady \& Nauta (1955) found no differences between the controls and habenular rats in acquisition of the response although rats lesioned prior to response acquisition showed a decreased resistance to extinction. However, the results of this experiment, when contrasted with the results of Nielson \& McIver (1966) clearly suggest that the acquisitions of active and passive avoidance responses are differentially effected by habenular lesions. Furthermore, it seems unlikely that the more rapid acquisition of the passive avoidance response is due to emotional freezing. Brady \& Nauta (1955) found no difference in emotional reactivity between habenular and control rats, on either a behavioral rating scale or a startle response. Also, Nielson \& McIver (1966) reported that habenular rats ambulated more in the open field, which is commonly taken as an indicant of decreased emotionality. Rather, the behavior of the rats suggested that the faster learning of this passive avoidance response shown by the habenular rats was due to reduced emotional reactivity following the lesion. On the first trial, two-thirds of the control rats stepped off the platform within 1 sec.; their behavior appeared to representattempts to escape. Only four habenular rats immediately stepped off the platform.

The results of this experiment may offer some additional support to the contention of Mess (1964) that the habenula is involved in the thyroidal response to cold since habenular lesions did reduce the serum inorganic levels, as did cold stress. However, the nature of the involvement is not clear. Nor is it clear why serum inorganic iodine levels of cold-stressed animals and of non-cold-stressed rats with lesions of the habenula are related to first trial response latency.

\section{References}

Brady, J. V., \& Nauta, W. J. H. Subcortical mechanisms in emotional behavior: The duration of affective changes following septal and habenular lesions in the albino rat. J. comp. physiol. Psychol., 1955, 48, 412-420.

Barker, S. B., Humphrey, M. J., \& Soley, M. H. The clinical determination of protein-bound iodine. J. clin. Invest., 1951, 30 , 55-63.

De Groot, $\mathbf{J}$. The rat forebrain in stereotaxic coordinates. Amsterdam: N. V. Noord-Hollandsche Uitgevers Maatschappij, 1959

Mess, B, Changes in thyroidal cold response of heat-adapted rats following bilaterà lesions of the habenular nuclei. Acta Physiol. Acad. Sci. Hung., 1964, 24, 299-304.

Nielson, H. C., \& McIver, Anstiss H. Cold stress and habenular effects on rat behaviors. $J$. appl. Physiol., in press.

\section{Notes}

1. This research was supported in part by Research Grant No. MH 07037-02 from the National Institute of Mental Health.

2. Now at Kansas State University. 